\title{
Chemical composition and application of flowers of false acacia (Robinia pseudoacacia L.)
}

\section{Stanko Stankov ${ }^{1}$, Hafize Fidan ${ }^{1}$, Tanya Ivanova ${ }^{1}$, Albena Stoyanova $^{1}$, Stanka Damyanova ${ }^{2}$, Mykola Desyk ${ }^{3}$}

\author{
1 - University of Food Technologies, Plovdiv, Bulgaria \\ 2 - University of Russe, Branch - Razgrad, Bulgaria \\ 3 - National University of Food Technologies, Kyiv, Ukraine
}

Keywords:

Robinia

pseudoacacia

Flower

Extracts

Chemical

Composition

Article history:

Received 13.06.2018

Received in revised form 27.08.2018

Accepted 27.12.2018

Corresponding author:

Hafize Fidan

E-mail:

hafizefidan@abv.bg

DOI: $10.24263 / 2304-$

974X-2018-7-4-4

$974 \times-2018-7-4-4$

\section{Abstract}

Introduction. The study was carried out to determine the chemical composition and biological activity of false acacia flowers and their products (concrete and syrups) grown in Bulgaria.

Materials and methods. Concrete was obtained by extraction with $\mathrm{n}$-hexane and its chemical composition was determined by GC-MS. Syrups with different concentrations have been obtained and their polyphenols content, antimicrobial and antioxidant activity were established.

Result and discussion. The yield of concrete was $1.06 \%$ and the major constituents of the concrete are as follows: n-nonacosane $(25.18 \%)$, n-heptacosane $(20.10 \%)$, $\alpha$-linolenic acid (5.97\%), n-pentacosane (4.98\%), palmitic acid $(4.92 \%)$, diisooctyl phthalate $(4.05 \%)$, hexahydrofarnesyl acetone $(3.86 \%)$, linoleic acid $(3.64 \%)$, isopropyl myristate (3.47\%), and n-hentriacontane $(3.39 \%)$. The total aliphatic hydrocarbons constituted the highest percentage of the component of the concrete constituting $61.50 \%$. The minerals identified as biggest content in the tested samples of false acacia flowers are nickel, copper, calcium and chromium.

Higher values of phenolic compounds in the flowers (0.77 mg GAE $/ \mathrm{mL})$ than those of the syrup $60^{\circ}$ Brix $(0.06$ $\mathrm{mg}$ GAE $/ \mathrm{mL})$ and $R$. pseudoacacia syrup $70^{\circ}$ Brix $(0.14$ $\mathrm{mg}$ GAE $/ \mathrm{mL}$ ) were found. The syrup samples exhibit antimicrobial properties against foodborne pathogenic bacteria as Salmonella, E. coli and L. monocytogenes.

Conclusion. Based on the chemical and biochemical properties of false acacia flowers, it could be recommended as a potential raw material for food, pharmaceutical and cosmetic products. 


\section{Introduction}

Robinia pseudoacacia L. (black locust, false acacia), belonging to the family of Fabaceae, originally native to the south-eastern USA, is widely distributed as wild and cultivated species growing in temperate regions throughout the world [1]. The genus Robinia commonly known as locust comprises 10 species of trees and shrubs characterized by white or pink flowers with intensive, distinctive, sweet aroma $[1,2]$. The flowers are white, borne in pendulous racemes of 10-15 cm long and are edible, with high nutrient and functional values. The flowers of false acacia are used in traditional medicine as diuretic, spasmolytic, sedative and cholagogic agents and relieve inflammation of the kidneys and biliary ducts [3, 4].

The investigation for chemical composition of $R$. pseudoacacia showed that flowers were rich in proteins and microelements which could be used for additives in foods [5, 6]. Its flowers also contained an important bioactive compound called robinin which had a lot of medicinal usage.

The review of the scientific literature indicated that flowers of false acacia, have been attracting a special interest due to their gentle fragrance, containing essential oil which composition depends on geographical region. Volatile compounds of flowers have been studied by several researchers, as well as aroma profiles in honey made from these flowers. In 1994, Kandem et al. [7] used Tenax tube cartridges to trap the floral fragrance of fresh false acacia and analyzed these volatile compounds using GC-MS. $\delta$-3-carene (54.6\%), linalool (21\%), (Z)- $\beta$-farnesene (3.0\%) and anthranilate aldehyde (3.9\%) were found to be the major components. Xie et al. [8] analyzed the chemical constituents of top fragrance from fresh flowers of false acacia growing in China using solid phase microextraction followed by GC-MS analysis and the main components were linalool (33.1\%), (E)- $\beta$-ocimene (26.6\%), (E)- $\alpha$-bergamotene $(8.9 \%)$ and formanilide $(7.4 \%)$.

The main bioactive components existed in false acacia flowers include flavonoids, phenolics, ascorbic acid, etc. [9, 10, 11, 12]. Flowers of false acacia contain volatile compounds, flavonoids, proteins, robinin, polysaccharide and some microelements [13].

Flavonoids content of false acacia is also of increasing interests to researchers. In 2000, five flavonoids including acacetin, secundiflorol, mucronulatol, isomucronulatol and isovestitol were isolated from ethanolic extracts of acacia, following an activity-guided fractionation $[14,15]$. Different parts of acacia have wide application in different areas. Its flowers could be eaten and are generally used for honey production. The flowers are also used for preparation of cakes. Series of findings support the consumption of edible flowers of the false acacia as functional food and their usage as sources of natural antioxidants in the food industry.

Recently, many investigations have been concerned with antioxidant properties of different nutritional products [16]. Antioxidant ability has usually been attributed to the activity of antioxidant enzymes as well as to the content of low-molecular antioxidants such as carotenoids, tocopherols, ascorbic acid, phenolic substances [3, 17, 18].

According to Marinas et al. [19], the alcoholic extracts of false acacia showed antimicrobial activity towards the tested strains belonging to the Gram-positive (Staphylococcus aureus, Bacillus subtilis and Enterococcus faecalis) and Gram-negative (Pseudomonas aeruginosa, Escherichia coli, Klebsiella pneumoniae and Acinetobacter baumannii) bacterial and the yeasts (Candida sp.) strains. Talas-Ogras et al. [20] studied the in vitro antibacterial activity of isolated from $R$. pseudoacacia seed and it had been found that the Staphylococcus aureus was the most sensitive strain compared with others strains 
(Corynebacterium michiganense, Bacillus subtilis, Erwinia carotovora, Pseudomonas syringae, Xanthomonas campestris and Escherichia coli).

Bhalla and Bajpai [21] reported significant antimicrobial effects against some of the selected foodborne pathogens such as Staphylococcus aureus KCTC 1621, Bacillus subtilis KCTC 3569, Listeria monocytogenes KCTC 3569, Escherichia coli O157:H7 and Salmonella enterica ATCC 4731 with diameters of the zones of inhibition (15.2 \pm 0.3 $17.3 \pm 2.0 \mathrm{~mm})$.

As unpretentious species regarding the environmental requirements, it has also adapted successfully to a diverse range of natural habitats in Bulgaria. Data relating to the pharmacological and botanical features of the species have been found in the literature. No detailed data for the composition and application of acacia flowers in the food industry have been found.

The aim of this study is to determine the chemical composition of false acacia (Robinia pseudoacacia L.) flowers and their potential application in the food, cosmetic and pharmacological industries.

\section{Materials and methods}

\section{Plant material}

False acacia flowers (R. pseudoacacia) were collected in May 2018 from a ten-fifteen years - old black locust tree, naturally growing in the foot of the Eastern Balkan Mountains, in the lands of the village of Topolchane, Sliven, Bulgaria. Samples were identified by an expert in Agricultural University of Plovdiv, Bulgaria.

The moisture content of the raw material $(83.7 \pm 0.03 \%)$ was determined by drying up to constant weight, at $105^{\circ} \mathrm{C}$ and all results have been presented on a dry weight basis [22].

\section{Obtaining and GC-MS analysis of concrete}

Concrete was obtained by two-stage, static batch extraction of $75 \mathrm{~g}$ flowers with $\mathrm{n}$ hexane under the following conditions: hydro module (raw material: solvent) $-1: 10(\mathrm{w} / \mathrm{v})$; duration of the first and second extraction stage $-1 \mathrm{~h}$ and $0.5 \mathrm{~h}$; temperature $40{ }^{\circ} \mathrm{C}$. The solvent was evaporated on a rotary vacuum evaporator at water bath temperature of $35{ }^{\circ} \mathrm{C}$ [23].

The GC-MS analysis was carried out with an Agilent 5975C MSD system coupled to an Agilent 7890A gas chromatograph (Agilent Technologies Inc., Santa Clara, CA). Agilent J\&W HP-5MS column $(0.25 \mu \mathrm{m}, 30 \mathrm{~m} \times 0.25 \mathrm{~mm})$ was used with helium as a carrier gas $\left(1.0 \mathrm{~mL} \mathrm{~min}^{-1}\right)$. The operational conditions were: oven temperature $35^{\circ} \mathrm{C} / 3 \mathrm{~min}, 5^{\circ} \mathrm{C} / \mathrm{min}$ to $250{ }^{\circ} \mathrm{C}$ for $3 \mathrm{~min}$, total run time $49 \mathrm{~min}$; injector temperature $260{ }^{\circ} \mathrm{C}$; ionization voltage 70 $\mathrm{eV}$; ion source temperature $230^{\circ} \mathrm{C}$; transfer line temperature $280^{\circ} \mathrm{C}$; solvent delay $4.25 \mathrm{~min}$ and mass range 50 - $550 \mathrm{Da}$. The MS was operated in scan mode. One $\mu \mathrm{L}$ of the sample diluted with $\mathrm{n}$-hexane $(10 \%, \mathrm{v} / \mathrm{v})$ was injected into the GC/MS system at split ratio $30: 1$. The GC analysis was carried out using an Agilent 7890 A GC system; FID temperature $270{ }^{\circ} \mathrm{C}$. In order to obtain the same elution order with GC/MS, simultaneous triplicate injections were done by using the same column and the same operational conditions.

The identification of compounds was made by comparing their mass spectra with those from mass spectra libraries [24] and by comparing the literature and estimated Kovat's (retention) indices that were determined using mixtures of homologous series of normal 
alkanes from $\mathrm{C}_{8}$ to $\mathrm{C}_{40}$ in hexane, under the conditions described above. The percentage ratio of volatile components was computed using the normalization method of the GC/FID peak areas.

\section{Mineral composition of flowers}

Content of selected elements was measured by ICP-AES spectrometer: SPECTROFLAME MODULA-FTMOA81A. $1 \mathrm{~g}$ of air dried sample flowers was weighed with precision up to $0.001 \mathrm{~g}$, and was poured on with $2 \mathrm{~cm}^{2}$ concentrated nitric acid. Mixture was cooled in freezer until end of foaming process, homogenized on vortex at 3000RPM, and was heated on thermoreactor KUTESZ type 656 at $120^{\circ} \mathrm{C}$ until dissolution of solid phase, and clarification of solution. After mineralization, the samples were filled up to $20 \mathrm{~mL}$ with $2 \%$ solution of nitric acid.

\section{Acacia syrup preparation}

For the preparation of the acacia syrups with different concentrations, anhydrous citric acid Parafarm (Saporiti, Argentina) was used to regulate the $\mathrm{pH}$, food grade sucrose, potable bottled water, each from the same batch, were bought from the local market.

The acacia flowers were stored at $5{ }^{\circ} \mathrm{C}$ for $24 \mathrm{~h}$. Acacia syrups are produced in two different concentrations.

For the obtaining of the lower concentration syrup the acacia flowers were extracted with a boiling $50 \%$ aqueous sugar solution for 10 minutes. Then, cooled in a cold water bath to $5{ }^{\circ} \mathrm{C}$. The extraction takes 24 hours under refrigeration conditions $\left(4^{\circ} \mathrm{C}\right)$ in the presence of flowers in the sugar syrup. Citric acid ( $1 \%$ by the weight of the final product) was added to the syrup. Total soluble solids (TSS) were up to $60^{\circ}$ Brix; water activity $-0.69 \pm 0.01$ (LabSwift-a , Novasina, Switzerland); $\mathrm{pH}-3.23 \pm 0.02$.

For the obtaining of the higher concentration syrup from acacia flowers, the common steps for preparation of extract were followed with the difference that they were subjected to extraction with a boiling aqueous solution of sugar $(50 \%)$ for $30 \mathrm{~min}$. Citric acid ( $1 \%$ by the weight of the final product) was added to the syrup. Total soluble solids (TSS) content reached $70{ }^{\circ}$ Brix; water activity $-0.67 \pm 0.01$ (LabSwift-aw, Novasina, Switzerland); $\mathrm{pH}-$ $3.19 \pm 0.02$.

The prepared syrups were filtered, cooled properly and poured into sterile glass bottles.

\section{Total phenolic contents}

Total phenolic content was measured using a Folin-Ciocalteu reagent. Briefly, $1 \mathrm{~mL}$ five times diluted Folin-Ciocalteu reagent was mixed with $0.2 \mathrm{~mL}$ sample and $0.8 \mathrm{~mL} 7.5 \%$ disodium carbonate. The reaction was performed for $20 \mathrm{~min}$ at room temperature in dark. Then the absorbance was measured at $765 \mathrm{~nm}$ against blank. The results were expressed as $\mathrm{mg}$ equivalent of gallic acid (GAE) per $\mathrm{mL}$ extract, according to calibration curve [25].

\section{Total flavonoids content}

The total flavonoids content was analyzed by aluminum trinitrate $\left(\mathrm{Al}\left(\mathrm{NO}_{3}\right)_{3}\right)$ reagents [26]. The absorbance was measured at $415 \mathrm{~nm}$ against blank. The results were presented as mg equivalents quercetin $(\mathrm{QE})$ per $\mathrm{g}$ dry extract according to the calibration curve with quercetin as a standard. 


\section{DPPH radical scavenging ability}

To conduct the assay, $0.15 \mathrm{~mL}$ from extract was mixed with $2.85 \mathrm{~mL}$ freshly prepared $0.1 \mathrm{~mol}$ solution of DPPH in methanol. The sample was incubated for $15 \mathrm{~min}$ at $37^{\circ} \mathrm{C}$ in darkness. The reduction of absorbance was measured at $517 \mathrm{~nm}$ in comparison to the blank containing methanol and\% inhibition were calculated [25].

\section{Ferric reducing antioxidant power (FRAP) assay}

The assay was performed according to Benzie and Strain [27] with slight modification by Kivrak et al. [26]. The FRAP reagent was freshly prepared by mixing 10 parts $0.3 \mathrm{M}$ acetate buffer (pH 3.6), 1 part $10 \mathrm{mM}$ 2,4,6- tripyridyl-s-triazine (TPTZ) in $40 \mathrm{mM} \mathrm{HCl}$ and 1 part $20 \mathrm{mM} \mathrm{FeCl} 3^{\times} 6 \mathrm{H}_{2} \mathrm{O}$ in distilled water. The reaction was started by mixing $3.0 \mathrm{~mL}$ FRAP reagent with $0.1 \mathrm{~mL}$ of investigated extract. The reaction time was $10 \mathrm{~min}$ at $37^{\circ} \mathrm{C}$ in darkness and the absorbance was measured at $593 \mathrm{~nm}$ against blank prepared with methanol. Antioxidant activity was expressed as $\mathrm{mM}$ Trolox ${ }^{\circledR}$ equivalents (TE) per $\mathrm{mL}$ extract [25].

\section{Microbiological analyses}

For the microbial analyses a crude extract was obtained under aseptic surroundings by mashing fresh flowers after preliminary washing under tap water, sterilized distilled water and soaking for $5 \mathrm{~min}$ with ethanol and exposing under the influence of ultraviolet illumination for $20 \mathrm{~min}$.

Antibacterial activity was tested against Gram-positive bacteria - Listeria monocytogenes NCTC 11994 and Staphylococcus aureus ATCC 25093, and Gram-negative bacteria - Escherichia coli ATCC 8739 and Salmonella enterica subsp. enterica serovar Abony NCTC 6017. The selective growth media, were: Listeria Oxford Agar Base /Merck/; Baird Parker Agar Base with Egg Yolk Tellurite emulsion supplement/Merck/, Rapid' E.coli 2 Agar/BioRad/ and Mac CONKEY Agar/Merck/, respectively. The media were inoculated with 24-hour suspension of the bacterial species.

\section{Antimicrobial assay by agar diffusion method}

The used inoculums have resulted as actual concentration cells of - Listeria monocytogenes, Staphylococcus aureus, Escherichia coli, Salmonella enterica into the responding selective medium about $1.10^{4} \mathrm{CFU} / \mathrm{mL}$. Melted and cooled to $45^{\circ} \mathrm{C}$ selective media were inoculated with the tested microorganisms and next equally dispensed into Petri dishes. After setting of the media, sterile rings $(\varnothing 6 \mathrm{~mm})$ were placed on, and different amounts of each sample $(0.05 ; 0.10$ and $0.15 \mathrm{~mL})$ were put into the rings. Petri dishes were incubated at $37^{\circ} \mathrm{C}$ for 24 or $48 \mathrm{~h}$ according to the bacterial spices, and then the distinct zone of growth inhibition around the rings was measured. The total plate count was estimated by the conventional plate-counting technique using appropriate dilution.

\section{Statistical analysis}

All experiments were performed in triplicate. All data were presented as mean \pm standard deviation (SD). 


\section{Results and discussion}

\section{Chemical composition of concrete}

The yield of concrete was $1.06 \%$ (in abs. dry mass). The concrete was yellow waxy pastes and had sharp odor. Chemical composition of the concrete was shown in Table 1.

The concrete was composed by 34 components representing $99.02 \%$ of its total content. Sixteen of them were in concentrations over $1 \%$ and the rest 18 constituents were in concentrations under $1 \%$.

Table 1

\section{Chemical composition of concrete}

\begin{tabular}{|c|l|c|c|}
\hline № & \multicolumn{1}{|c|}{ Compound } & RI & Content, $\%$ \\
\hline 1 & trans-Linalyl Oxide & 1074 & 0.48 \\
\hline 2 & cis-Linalyl Oxide & 1088 & 0.65 \\
\hline 3 & Methyl salicylate & 1175 & 1.06 \\
\hline 4 & p-Anisic acid & 1399 & 0.81 \\
\hline 5 & n-Pentadecane & 1500 & 1.12 \\
\hline 6 & n-Hexadecane & 1600 & 0.37 \\
\hline 7 & Methyl veratrate & 1602 & 0.78 \\
\hline 8 & cis-Methyl dihydrojasmonate & 1654 & 0.69 \\
\hline 9 & n-Heptadecane & 1700 & 0.58 \\
\hline 10 & E,E)-farnesol & 1722 & 0.41 \\
\hline 11 & E,Z)-farnesol & 1744 & 0.51 \\
\hline 12 & n-Octadecane & 1800 & 0.33 \\
\hline 13 & Isopropyl myristate & 1814 & 3.47 \\
\hline 14 & Hexahydrofarnesyl acetone & 1833 & 3.86 \\
\hline 15 & Diisobutyl phthalate & 1862 & 1.52 \\
\hline 16 & Methyl isopalmitate & 1891 & 0.59 \\
\hline 17 & Dibutyl phthalate & 1914 & 1.38 \\
\hline 18 & Palmitic acid & 1942 & 4.92 \\
\hline 19 & Isopropyl hexadecanoate & 1989 & 0.72 \\
\hline 20 & Linoleic acid & 2098 & 3.64 \\
\hline 21 & $\alpha$-Linolenic acid & 2106 & 5.97 \\
\hline 22 & Tributyl acetylcitrate & 2259 & 0.84 \\
\hline 23 & n-Pentacosane & 2500 & 4.98 \\
\hline 24 & Diisooctyl phthalate & 2589 & 4.05 \\
\hline 25 & n-Hexacosane & 2600 & 0.63 \\
\hline 26 & n-Heptacosane & 2700 & 20.10 \\
\hline 27 & n-Octacosane & 2800 & 1.05 \\
\hline 28 & all-trans-Squalene & 2835 & 0.59 \\
\hline 29 & n-Nonacosane & 2900 & 25.18 \\
\hline 30 & n-Triacontane & 3000 & 1.86 \\
\hline 31 & n-Hentriacontane & 3100 & 3.39 \\
\hline 32 & n-Dotriacontane & 3200 & 0.72 \\
\hline 33 & $\beta$-Amyrin & 3290 & 0.84 \\
\hline 34 & $\alpha$-Amyrin & 0.93 \\
\hline & & \\
\hline
\end{tabular}


As could be seen the major constituents (up 3\%) of the concrete are as follows: $n$ nonacosane $(25.18 \%)$, n-heptacosane $(20.10 \%)$, $\alpha$-linolenic acid $(5.97 \%)$, n-pentacosane (4.98\%), palmitic acid (4.92\%), diisooctyl phthalate $(4.05 \%)$, hexahydrofarnesyl acetone $(3.86 \%)$, linoleic acid (3.64\%), isopropyl myristate (3.47\%), and n-hentriacontane $(3.39 \%)$. The difference in chemical composition of our investigations and the reported data may be due to environmental conditions under which the plant has grown as well as the variation in conditions of the analysis.

The classification of the identified compounds, based on functional groups, is presented in Figure 1.

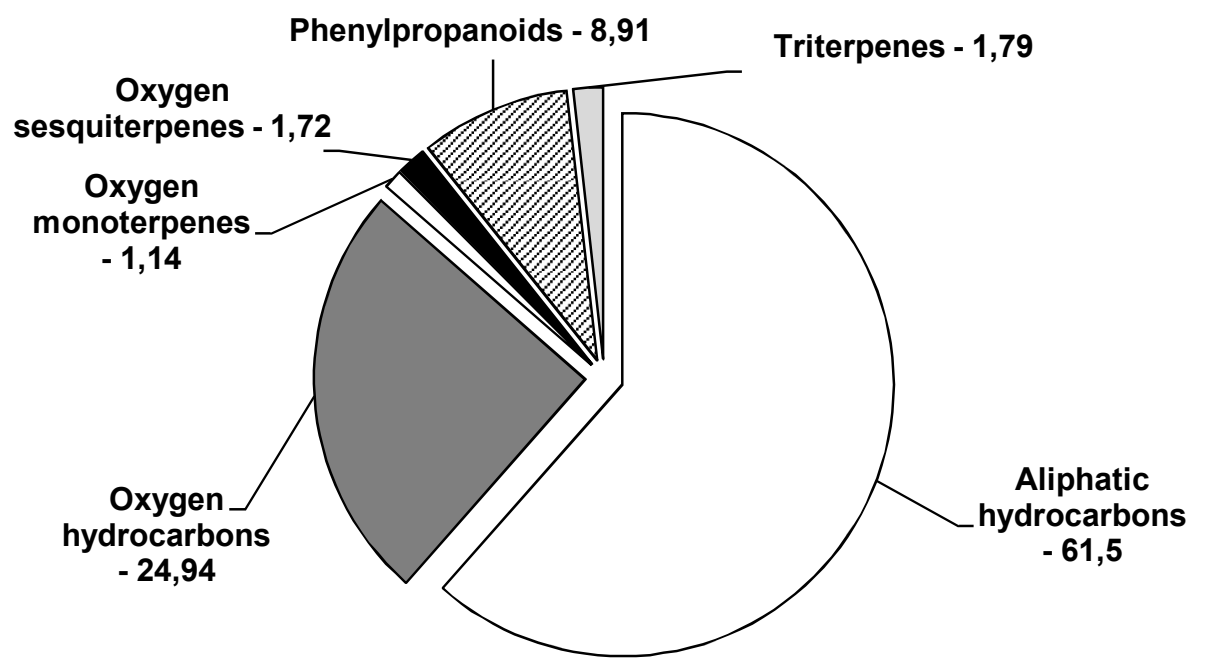

Components in concrete [\%]

Figure 1. Groups of components in concrete

The total aliphatic hydrocarbons constituted the highest percentage of the component of the concrete constituting $61.50 \%$. The concrete consisted above $10 \%$ concentration oxygen hydrocarbons $(24.94 \%)$. The percentage of phenylpropanoids, triterpenes, oxygen sesquiterpenes and oxygen monoterpenes are under $9 \%$.

\section{Mineral composition of flowers}

The minerals identified in the tested samples of false acacia flowers are as follows: boron $-182.64 \mathrm{~nm}$, arsenic $-188.98 \mathrm{~nm}$, zinc $-213.86 \mathrm{~nm}$, manganese -257.61 , iron $259.54 \mathrm{~nm}$, and magnesium $-279.81 \mathrm{~nm}$, and chromium $-283.56 \mathrm{~nm}$, calcium $-317.93 \mathrm{~nm}$, copper $-324.75 \mathrm{~nm}$ and nickel $-341.48 \mathrm{~nm}$.

Differences in identified elements relative to other researchers may be due to environmental factors (geographical, climatic and seasonal). The relatively high levels of microelements, iron $259.54 \mathrm{~nm}$ is found in the active sites of many redox enzymes and 
electron carriers such as hemoglobin and myoglobin, and therefore may have potential functional benefits in the human body. Copper $(324.75 \mathrm{~nm}$ ) has an important role in the active site of many redox enzymes and electron carriers, the production of hemoglobin or bone formation. Manganese $(257.61 \mathrm{~nm})$ activates many enzymes.

\section{Content of polyphenolics and flavonoids}

The extract of flowers presented the highest phenolic content $(0.77 \mathrm{mg} \mathrm{GAE} / \mathrm{mL})$, followed by the acacia syrup $70{ }^{\circ} \mathrm{Brix}(0.14 \mathrm{mg} \mathrm{GAE} / \mathrm{mL})$ (Figure 2). Among the samples, false acacia flowers have the highest value for flavonoids $(0.17 \mathrm{mg} \mathrm{QE} / \mathrm{mL})$, the total phenolic content was $0.77 \mathrm{mg} \mathrm{GAE} / \mathrm{mL}$. With regard to the heating in the extract and syrup could rapidly flow inactivation of polyphenol oxidases, presented in flowers. Cooking with heat may lead to a higher extraction efficiency of total phenolics through destroying of the cell structure, which may lead to better solvent access and extraction.

Acacia flowers presented the highest flavonoids content $(0.17 \mathrm{mg} \mathrm{QE} / \mathrm{mL})$, followed by the acacia syrup $60^{\circ}$ Brix $(0.07 \mathrm{mg} \mathrm{QE} / \mathrm{mL})$, and syrup $70{ }^{\circ}$ Brix $(0.04 \mathrm{mg} \mathrm{QE} / \mathrm{mL})$, respectively (Figure 2).

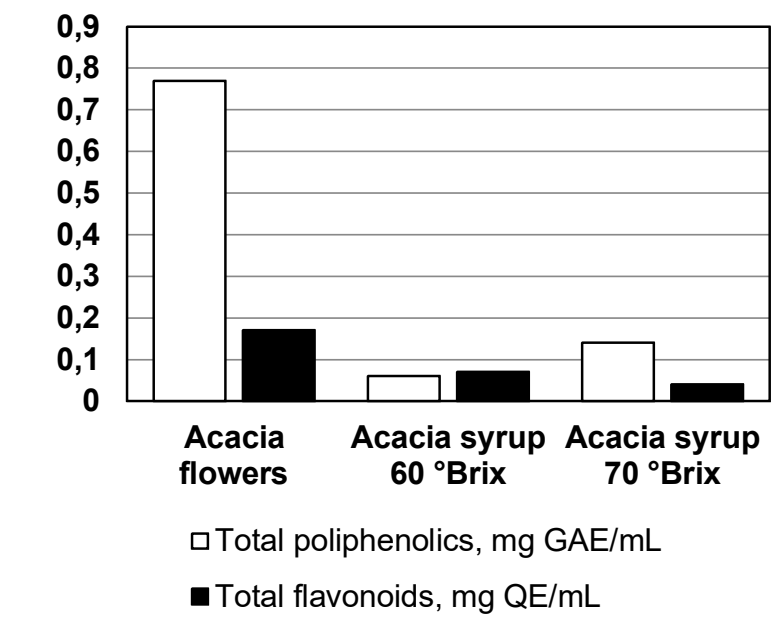

${ }^{* 1}$ GAE - Gallic Acid Equivalents, $\quad{ }^{2} \mathrm{QE}$ - Quercets Equivalents

Figure 2. The total polyphenolics and flavonoids on $R$. pseudoacacia flowers and syrups

The results obtained in this study showed that the flowers are rich in phenolic compounds and have significant antioxidant activity. Flowers of false acacia as a natural additive in food, cosmetic and pharmaceutical products could be used as effective strategy to improve their nutritional and medical value while ensuring consumer safety.

\section{Antioxidant activity}

There have been few reports on the antioxidant activity of false acacia extracts. The antioxidant activity of lyophilized extracts of acacia leaves had a lower antioxidant capacity (1940 $\mu \mathrm{mol}$ Trolox equivalent $\left.\mathrm{g}^{-1}\right)$ compared with Rhus typhina $(4651 \mu \mathrm{mol}$ Trolox 
equivalent $\left.\mathrm{g}^{-1}\right)$, Acer rubrum ( $3805 \mu \mathrm{mol}$ Trolox equivalent $\left.\mathrm{g}^{-1}\right)$, and Rosa multiflora (2533 $\mu$ mol Trolox equivalent $\mathrm{g}^{-1}$ ) [28]. Recently, Marinas et al. [19] reported that the highest content of polyphenols (GAE) was found in the leaf extract (266.7 $\mu \mathrm{g} \mathrm{GAE} \mathrm{mL}^{-1}$ extract), followed by the extract of the seeds ( $232.2 \mu \mathrm{g} \mathrm{GAE} \mathrm{mL}^{-1}$ extract), respectively. In addition, the content of polyphenols presented in the flowers creates a strong antioxidant potential [29]. Differences in the distribution of the polyphenols and flavonoids arise from various factors that can be biological e.g., the part analyzed and the vegetative stage of the plant [30] and technical such as the extraction method, the solvents and their concentrations [31,32] and there are also differences in the structure and properties of the phenolic compounds presented in the different samples analysed. False acacia flowers have the highest antioxidant activities - radical scavenging activity (DPPH $-2.25 \mathrm{mM} \mathrm{TE} / \mathrm{ml}$ ) and metal reducing ability (CuPRAC $-4.52 \mathrm{mM} \mathrm{TE} / \mathrm{mL}$ ) (Figure 3).

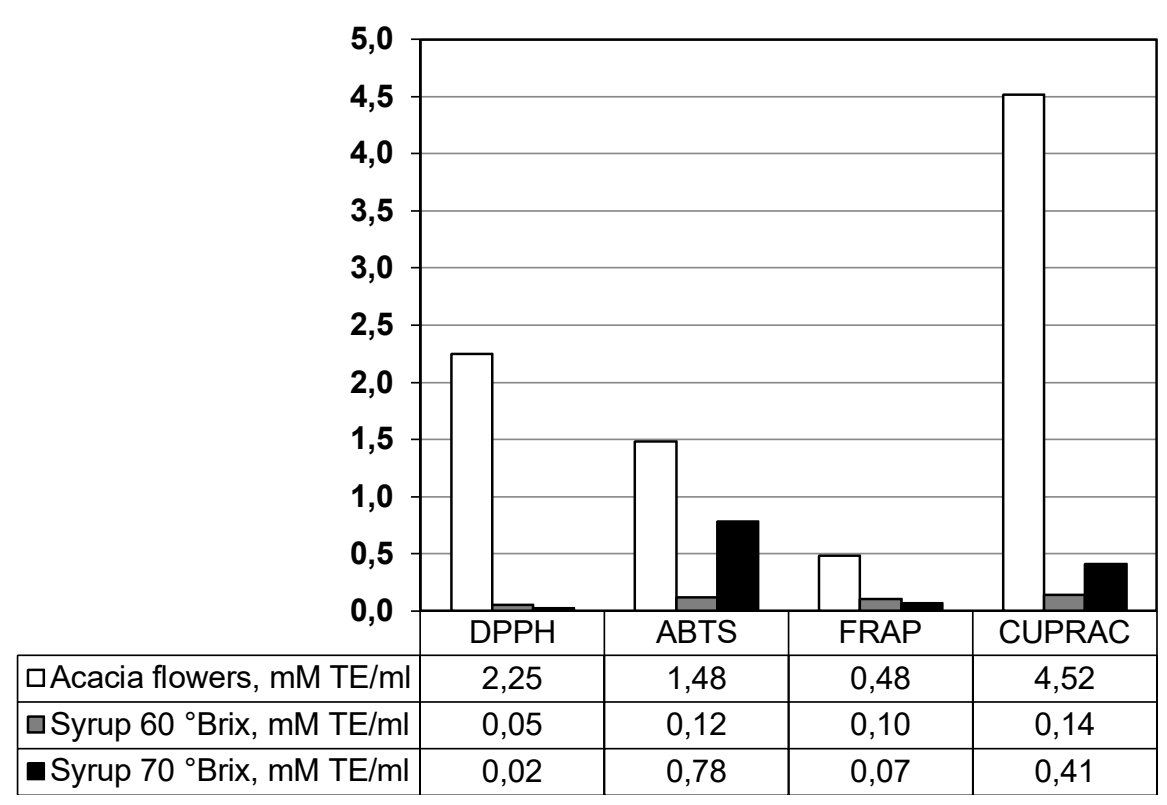

Figure 3. Antioxidant activity of acacia flowers and syrups

Higher values of isolated metals as copper $-324.75 \mathrm{~nm}$ and nickel $-341.48 \mathrm{~nm}$ are directly related to the antioxidant properties of acaci flowers.

\section{Microbiological analyses}

The results of antibacterial testing are presented in Table 2 . 
Diameter of zones of growth inhibition $(\mathrm{mm})$ of tested pathogenic bacteria

\begin{tabular}{|c|c|c|c|c|c|}
\hline \multicolumn{2}{|l|}{ Sam } & E.coli & Salmonella & $\begin{array}{c}L . \\
\text { mono } \\
\text { cytogenes }\end{array}$ & S. aureus \\
\hline & & \multicolumn{4}{|c|}{ Zones of growth inhibition (mm) } \\
\hline \multirow[t]{3}{*}{ Flowers } & $0.15 \mathrm{~mL}$ & 25.00 & 16.00 & 21.00 & 0.00 \\
\hline & $0.10 \mathrm{~mL}$ & 24.00 & 8.00 & 19.00 & 0.00 \\
\hline & $0.05 \mathrm{~mL}$ & 4.00 & 4.00 & 0.00 & 0.00 \\
\hline \multirow{3}{*}{$\begin{array}{l}\text { Syrup } \\
60^{\circ} \text { Brix }\end{array}$} & $0.15 \mathrm{~mL}$ & 18.00 & 13.00 & 0.00 & 0.00 \\
\hline & $0.10 \mathrm{~mL}$ & 10.00 & 0.00 & 0.00 & 0.00 \\
\hline & $0.05 \mathrm{~mL}$ & 0.00 & 0.00 & 0.00 & 0.00 \\
\hline \multirow{3}{*}{$\begin{array}{l}\text { Syrup } \\
70^{\circ} \text { Brix }\end{array}$} & $0.15 \mathrm{~mL}$ & 20.00 & 15.00 & 20.00 & 0.00 \\
\hline & $0.10 \mathrm{~mL}$ & 14.00 & 7.00 & 12.00 & 0.00 \\
\hline & $0.05 \mathrm{~mL}$ & 5.00 & 6.00 & 5.00 & 0.00 \\
\hline
\end{tabular}

The crude extract of false acacia, applied in an amount of $0.15 \mathrm{~mL}$, possessed the most pronounced antibacterial activity with inhibition zones: $25.00 \mathrm{~mm}$ against $E$. coli, $21.00 \mathrm{~mm}$ against L. monocytogenes and $16.00 \mathrm{~mm}$ against Salmonella enterica. False acacia crude extract had no inhibitory activity against $S$. aureus.

It is obvious that $S$. aureus was most resistable bacterium. False acacia syrup $60{ }^{\circ}$ Brix, applied in an amount of $0.15 \mathrm{~mL}$ showed highest antibacterial potential against $E$. coli with a zone of inhibition of $18 \mathrm{~mm}$ and at the lowest sample concentration $(0.05 \mathrm{~mL})$ is ineffective. False acacia syrup $60^{\circ}$ Brix was effective against Gram-negative bacteria and didn't inhibit the growth of the Gram-positive. False acacia syrup $70^{\circ}$ Brix showed antibacterial activity against E. coli, Salmonella and L. monocytogenes in all applied concentrations. The antibacterial activity of false acacia syrups with different Total Soluble Solids content is considered to be due to the high sugar content in their composition.

It is obvious from the results that the activity of the false acacia extract depended on its concentration and the tested bacteria. This affirmation could be confirmed by the concluded results of Cioch et al. [33] reported that the type of the extract (ethanol, methanol or water) and the concentration of black locust displayed distinction in the level of inhibition the growth of microorganisms used in their experiments. In the case of most microorganisms, it is reported that their growth was inhibited by concentration of $2.00 \mathrm{mg} / \mathrm{mL}$. Rosu et al. [34] reported that extracts from different parts of the plant had different antibacterial activities. Extracts of false acacia flowers and seeds were efficient antibacterials for Gram positive cocci. Bark and leaf extracts were active against E. coli, Pseudomonas, Proteus, Salmonella choleraesuis, Candida albicans.

\section{Conclusion}

The present study shows that flowers of false acacia ( $R$. pseudoacacia L.) were with high levels of phenolic compounds and minerals that have pronounced antioxidant properties. Probably, most of the phytochemicals have preserved during the heat treatment of the syrup. 
Higher values of phenolic compounds in the flowers $(0.77 \mathrm{mg} \mathrm{GAE} / \mathrm{mL})$ than those of the false acacia syrup $60^{\circ} \mathrm{Brix}(0.06 \mathrm{mg} \mathrm{GAE} / \mathrm{mL})$ and false acacia syrup $70^{\circ} \mathrm{Brix}(0.14 \mathrm{mg}$ $\mathrm{GAE} / \mathrm{mL}$ ) were found. The aromatic substances and phenolic compounds passing through the extracts exhibit antimicrobial properties against foodborne pathogenic bacteria as Salmonella, E. coli and L. monocytogenes. This is a reason for more thorough examination and extensive research of the chemical and biochemical properties of false acacia flowers as a potential raw material for usage in the food, pharmaceutical and cosmetic industries.

\section{References}

1. Hegi G. (1924), Illustrierte Flora von Mittel Europa. Bd. IV/3, Lehmanns, Munchen.

2. Tutin T., Heywood V., Burges N., Moore D., Valentine D., Walters S., Webb D. (1968), Flora Europea, University Press, Cambridge.

3. Pietta P., Simonetti P., Mauri P. (1998), Antioxidant activity of selected medicinal plants, Journal of Agricultural and Food Chemistry, 46, pp. 4487-4490.

4. Strzelecka H., Kowalski J. (2000), The Encyclopedia of Herbs and Herbalism, PWN, Warszawa.

5. Robards K., Prenzler P., Tucker G., Swatsitang P., Glover W. (1999), Phenolic compounds and their role in oxidative processes in fruits, Food Chemistry, 66, pp. 401-436.

6. Song Y., Luo J., Xie H. (1992), Study on the chemical composition of Robinia pseudoacacia flowers, Chemistry and Industry of Forest Products, pp. 1-4.

7. Kandem D., Gruber K., Barkman T., Gage D. (1994), Characterization of black locust floral fragrance, Journal of Essential Oil Research, 6, pp. 199-200.

8. Xie J., Sun B., Yu M. (2006), Constituents of top fragrance from fresh flowers of Robinia Pseudoacacia L. occurring in China, Flavour and Fragrance Journal, 21, pp. 798-800.

9. Jing L., Qiu H., Yang L., Liu M., Gao Z. (2002), Nutrition in the Pagoda flower (in Chinese), Chinese Journal Spectroscopy. Lab., 19, pp. 36-38.

10. Li Y., Chu Z., Zhai Y., Kang T. (2011), Preparation technique of total flavone of Robinia psendoacacia (in Chinese), Journal of Liaoning University. TCM, 13, pp. 87-88.

11. Wang X., Tang L., Zhao L., Luan Y., Zhang Z. (2010), Determination of polyphenols in flowers of R. pseudoacacia L. by Folin-ciocaileu method (in Chinese), Food Drug, 12, pp. 332-334.

12. Wang X., Tang L., Zhao L. (2011), Optimization of ultrasound-assisted extraction of phenolic compounds from $R$. pseudoacacia L. flowers by response surface methodology, Food Science., 32, pp. 66-40.

13. Giet C., Ziegler H. (1980), Distribution of carbohydrate-binding proteins in different tissues of Robinia pseudoacacia L., Biochemie und Physiologie der Pflanzen, 175, pp. 58-66.

14. Tian F., McLaughlin J. (2000), Bioactive flavonoids from the black locust tree, Robinia pseudoacacia, Pharmaceutical Biology, 38, pp. 229-334.

15. Vinson J., Hao Y., Su X., Zubik L. (1998), Phenol antioxidant quantity and quality in foods: vegetables, Journal of Agricultural and Food Chemistry, 46, pp. 3630-3634.

16. Velioglu Y., Mazza G., Gao L., Oomah B. (1998), Antioxidant activity and total phenolics in selected fruits, vegetables and grain products, Journal of Agricultural and Food Chemistry, 46, pp. 4113-4117.

17. Bartosz G. (1997), Oxidative stress in plants, Acta Physiologiae Plantarum, 19, pp. 47-64.

18. Larson R. (1988), The antioxidants of higher plants, Phytochemistry, 27, pp. 969-978.

19. Marinas I., Oprea E., Geana E.I., Chifiriuc C., Lazar V. (2014), Antimicrobial and antioxidant activity of the vegetative and reproductive organs of Robinia pseudoacacia, $J$. Serb. Chem. Soc., 79, pp. 1363-1378. 
20. Talas-Ogras T., Ipekci Z., Bajrovic K., Gozukirmizi N. (2005), Antibacterial activity of seed proteins of Robinia pseudoacacia, Fitoterapia, 76, pp. 67-72.

21. Bhalla P., Bajpai V. (2017), Chemical Composition and antibacterial action of Robinia pseudoacacia L. flower essential oil on membrane permeability of foodborne pathogens, Journal of Essential Oil-Bearing Plants, 20, pp. 1-14.

22. Russian Pharmacopoeia, $11^{\text {th }}$ Edition, Moscow. (1990),

23. Stoyanova A., Georgiev E., Atanasova T. (2007), Handbook for Laboratory Practice in Essential Oils, Acad. Publ. House of the University of Food Technologies, Plovdiv (in Bulgarian).

24. Adams R. (2001), Identification of Essential Oil Components by Gas Chromatography Quadrupole Mass Spectroscopy. Carol Stream, Illinois.

25. Ivanov I., Vrancheva R., Marchev A., Petkova N., Aneva I., Denev P., Georgiev V., Pavlov A. (2014), Antioxidant activities and phenolic compounds in Bulgarian Fumaria species, International Journal of Current Microbiology and Applied Sciences, 3, pp. 296-306.

26. Kivrak I., Duru M., Öztürk M., Mercan N., Harmandar M., Topçu G. (2009), Antioxidant, anticholinesterase and antimicrobial constituents from the essential oil and ethanol extract of Salvia potentillifolia, Food Chemistry, 116, pp. 470-479.

27. Benzie F., Srain J. (1996), Ferric reducing ability of plasma (FRAP) as a measure of "antioxidant power": The FRAP assay, Analytical Biochemistry, 239, pp. 70-76.

28. Katiki L., Ferreira J. , Gonzalez J., Zajac A., Lindsay D., Chagas A., Amarante A. (2013), Anthelmintic effect of plant extracts containing condensed and hydrolyzable tannins on Caenorhabditis elegans, and their antioxidant capacity, Vet. Parasitol., 192, pp. 218-227.

29. Zhang L., Ji H., Du A., Xu C., Yang M., Li F. (2012), Effects of drying methods on antioxidant properties in Robinia pseudoacacia L. flowers, J. Med. Plants Res., 6, pp. 32333239.

30. Ksouri R., Megdiche W., Falleh H., Trabelsi N., Boulaaba M., Smaoui A., Abdelly C. (2008), Influence of biological, environmental and technical factors on phenolic content and antioxidant activities of Tunisian halophytes, Comptes Rendus Biologies, 331, pp. 865-873.

31. Gallego M., Gordon M., Segovia F., Skowyra M., Almajano M. (2013), Antioxidant properties of three aromatic herbs (rosemary, thyme and lavender) in oil-in-water emulsions, J. Am. Oil Chem. Soc., 90, pp. 1559-1568.

32. Santas J., Carbó R., Gordon M., Almajano M. (2008), Comparison of the antioxidant activity of two Spanish onion varieties, Food Chemistry, 107, pp. 1210-1216.

33. Cioch M., Satora P., Skotniczny M., Semik-Szczurak D., Tarko T. (2017), Characterisation of antimicrobial properties of extracts of selected medicinal plants, Polish Journal of Microbiology, 66, pp. 463-472.

34. Rosu A., Bita A., Calina D., Rosu L., Zlatian O., Caliva V. (2012), Synergic antifungal and antibacterial activity of alcoholic extract of the species Robinia pseudoacacia L. (Fabaceae), European Journal of Hospital Pharmacy: Science and Practice,19, p. 216. 